\title{
Awareness Level Evaluation of Dental Professionals on Zoonoses
}

\section{Diş Hekimlerinin Zoonotik Hastalıklar Konusunda Farkındalığının Değerlendirilmesi}

(D) Ezgi EROĞLU ÇAKMAKOĞLU1, iD Adalet ÇELEBİ2

${ }^{2}$ Bingöl University Faculty of Dentistry, Department of Pediatric Dentistry, Bingöl, Turkey

Mersin University Faculty of Dentistry, Department of Oral, Dental and Maxillofacial Surgery, Bingöl, Turkey

\begin{abstract}
Objective: This study aimed to evaluate the awareness level of dental professionals on zoonoses and surveys and raise their awareness of the "one health" concept, which is a key policy that was adopted by veterinarians, physicians, and other health professionals to attain definitive outcomes in the fight against zoonoses.
\end{abstract}

Methods: The study included dental professionals working at the state, private universities, and private clinics in Turkey who completed an 18-item online survey between March and April 2020.

Results: This study included 603 dental professionals who completed the survey form. Participants that were specialized in pedodontics, oral and maxillofacial radiology, and restorative dentistry had a significantly higher level of knowledge about the types of zoonoses compared to nonspecialized participants. Similarly, participants who were specialized in oral and maxillofacial radiology had a significantly higher level of knowledge about the types of zoonoses compared to participants who were specialized in oral and maxillofacial surgery, orthodontics, prosthetic dentistry, and endodontics. Nevertheless, no significant difference was established among other fields of specialty about the knowledge level on the types of zoonoses. Contrarily, $96.19 \%$ of participants reported no knowledge about the "one health" concept.

Conclusion: Activities on zoonoses should be promoted and training schemes should be conducted to inform dental professionals and other health professionals on zoonoses.

\section{ÖZ}

Amaç: Diş hekimlerinin zoonozlar konusundaki farkındalık düzeyini değerlendirmek ve aynı zamanda, veteriner hekimler, hekimler ve diğer sağlık profesyonelleri tarafından zoonotik hastalıklar ile mücadelede kesin sonuçlara ulaşmak için benimsenen anahtar bir politika olan "Tek Sağlık” kavramı hakkında araştırma yapmak ve farkındalıklarını artırmak.

Yöntemler: Türkiye'de kamu, üniversite ve özel kliniklerde çalışan diş hekimlerine tanımlayıcı 18 soruluk anket Mart-Nisan 2020 tarihlerinde uygulanmışır. Katılımcılara demografik bilgileri ve zoonotik hastalıklar konusundaki farkındalıklarını değerlendirecek sorular sorulmuştur.

Bulgular: Toplamda 603 diş hekimliği uzmanı anket formunu doldurdu ve çalışmaya dahil edildi. Pedodonti, oral ve maksillofasiyal radyoloji ve restoratif diş hekimliği alanlarında uzmanlaşmış katılımcılar, uzman olmayanlara göre zoonotik hastalıklar hakkında önemli ölçüde daha yüksek bilgi düzeyine sahiptiler. Benzer şekilde, oral ve maksillofasiyal radyoloji konusunda uzmanlaşmış katılımcılar, ağız ve çene cerrahisi, ortodonti, protez diş hekimliği ve endodonti alanlarında uzmanlaşmış katılımcılara kıyasla zoonoz türleri hakkında önemli ölçüde daha yüksek bilgi düzeyine sahipti. Bununla birlikte, zoonoz türleri hakkında bilgi düzeyi açısından diğer uzmanlık alanları arasında önemli bir farklılık tespit edilmemiştir. Öte yandan, katılımcıların \%96,19’u "Tek Sağlık” kavramı hakkında hiçbir bilgisi olmadığını belirtmiştir.

Sonuç: Diş hekimleri ve diğer tüm sağlık çalışanlarının zoonoz hastalıklar konusunda bilgilendirilmesine ve bu konu hakkında
Address for Correspondence: Adalet ÇELEBI, Mersin University Faculty of Dentistry, Department of Oral, Dental and Maxillofacial Surgery, Bingöl, Turkey

E-mail: adalet_celebi@hotmail.com ORCID ID: orcid.org/0000-0003-2471-1942
Received: 12.08 .2020

Accepted: 28.12 .2020

Cite this article as: Eroğlu Çakmakoğlu E, Çelebi A. Awareness Level Evaluation of Dental Professionals on Zoonoses. Bezmialem Science 2022;10(1):53-61 
Additionally, dental professionals and other health professionals need to learn about and adopt the "one health" concept.

Keywords: Dentistry, zoonotic disease, "one health" concept yapılacak çalışmalara ihtiyaç duyulmaktadır. Ayrıca özellikle zoonoz hastalıklar konusunda "Tek Sağlık" konseptinin benimsenmesi gerekmektedir.

Anahtar Sözcükler: Diş hekimliği, zoonotik hastalıklar, "Tek Sağlık" konsepti

\section{Introduction}

The link between human and animal medicine has been a major concern among researchers for more than 150 years. As a pioneering proponent, German physician and pathologist, Rudolph Virchow, proposed that there is and will be no clear-cut distinction between human and animal medicine and coined the term "zoonosis," which means a disease that can be transmitted from vertebrate animals to humans, based on his animal experimentation on the life cycle of Trichinella spiralis (1).

Zoonoses account for up to $60 \%$ of all known human infections and $>75 \%$ of the emerging pathogens. These diseases are mostly classified based on the nature of the pathogen, animal host, disease severity, and the mode of transmission among animals or humans $(2,3)$. The infection in zoonotic diseases results from the exposure of a sensitive population to the pathogenic microorganism. Contrarily, zoonoses may spread across the world during the mass immigration of infected humans or animals $(3,4)$. Moreover, these diseases may be transmitted by contact with all contaminated animals, including poultry, birds, rodents, pets, cattle, bovines, sheep-goats, wild animals, and prey animals (5).

Zoonoses show wide variation due to the variation of microorganisms and transmission modes (animal-animal, animal-human, human-human, and human-animal). Among the most common zoonoses reported in Europe in 2016, Campylobacter was the most frequently seen infection since 2005 and accounted for up to $70 \%$ of all cases, followed by Salmonella, Yersinia, Escherichia coli, Listeria, Q fever, tularemia, Echinococcus, and brucellosis (6). In addition to bacterial pathogens, viral, fungal, and parasitic agents can also be a cause of zoonoses. Common zoonoses include rabies, tuberculosis, bird flu, severe acute respiratory syndrome (SARS), leishmaniasis, capillariasis, anthrax, Crimean-Congo hemorrhagic fever (CCHF), and human immunodeficiency virus (HIV) (7).

Zoonoses are a leading cause of death from infectious diseases worldwide $(8,9)$. A previous study that investigated the global effect of zoonoses on morbidity and mortality revealed that zoonoses are responsible for approximately 2.7 million human deaths and 2.5 billion cases of human illness annually worldwide (10). Zoonoses in Turkey, particularly, including CCHF, anthrax, rabies, and brucellosis, remain a significant public health problem. Besides their adverse public health impact, zoonoses also lead to large economic losses due to productivity loss and death in animals $(11,12)$. Complete eradication of zoonoses seems unlikely; however, their spread can be prevented by taking appropriate measures (13).
Dr. Calvin W. Schwabe established the "One Health" concept in the 1960s, calling upon all health professionals, including veterinarians, to collaboratively work against zoonoses (14). In 2004, the "One World-One Medicine-One Health" concept was established based on the "One Medicine" concept and advocated a collaborative fight against zoonoses by a combination of human and animal medicine $(14,15)$. As a concept involving both ecosystem and wildlife health, the "One Health" concept comprises a global strategy that emphasizes the need for a holistic and interdisciplinary approach and incorporates multisector expertise in coping with the health of mankind, animals, and the ecosystem $(15,16)$.

Dental professionals can be exposed to numerous pathogenic microorganisms, including viruses and bacteria that infect the oral cavity and respiratory tract. Additionally, both dental professionals and dental care settings invariably have an increased risk of infection due to the specificity of their procedures that involve face-to-face communication with patients, contact with saliva, blood, and other body fluids, and the use of sharp tools $(17,18)$. Contrarily, pathogenic microorganisms can be transmitted in dental settings through inhalation of airborne microorganisms that can remain suspended in the air for long periods (19). These notions indicate that dental practices facilitate the human-human transmission of zoonoses. The present study aimed to evaluate the awareness level of dental professionals on zoonoses and survey and raise their awareness of the "One Health" concept, which is a key concept in the transmission and distribution of zoonoses (20).

\section{Methods}

An accuracy test was performed using a serial approach to assess the validity and reliability of the survey that is used in the study (21). The survey questions were prepared as authentic, reliable, and valid items. Data were collected using an online survey created by Google Forms that was administered to dental professionals working at the state, private universities, and private clinics in Turkey between March and April 2020. The survey was administered to dentists who were actively working in Turkey who either had a bachelor's degree or had been specialized in any subfield of dentistry. The target participants were informed about the survey via text messages and emails and were requested to participate in the study. This study included 603 dental professionals who completed the survey form. The survey consisted of 18 items that probe participants' demographic features (e.g., professional setting, the year of starting to work), knowledge on zoonoses (sources, causes, transmission modes of zoonoses, and methods of knowledge acquisition), and their 
awareness level about the implementation of the "One Health" concept against zoonoses (Table 1). Before the study, approval was obtained from Firat University Non-interventional Clinical Research Ethics Committee (approval date: March 5, 2020; no: 2020/05-08). Each participant was informed about the goals and anticipated outcomes of the study.

\section{Statistical Analysis}

Data were analyzed using International Business Machines Statistical Package for the Social Sciences Statistics Version 25 (Armonk, NY: IBM Corp.). Nominal variables were compared using the Chi-square test. $\mathrm{RxC}$ tables were analyzed using Pearson's chi-square test with Monte Carlo simulation. Differences between group means of data with nonnormal distribution were assessed using the Mann-Whitney $U$ test and Kruskal-Wallis $\mathrm{H}$ test followed by a post hoc test. A p-value of $<0.05$ was considered significant.

\section{Results}

The survey form was completed by 603 dental professionals, wherein $63.18 \%$ were female and $36.82 \%$ were male. Of all participants, $1.33 \%$ graduated before $1990,1.49 \%$ in 1990 $1994,1.82 \%$ in $1995-1999,39.47 \%$ in $2000-2014$, and $55.89 \%$ in 2015-2019. Additionally, 34.49\% were working at a private clinic, $25.87 \%$ in a specialty program or doctoral degree, $25.7 \%$ at an oral and dental health clinic, and $13.93 \%$ as an academician at a university. Moreover, $51.08 \%$ were nonspecialized, whereas $11.94 \%$ had a specialty in oral and maxillofacial surgery, $7.79 \%$ in prosthetic dentistry, $6.8 \%$ in endodontics, $6.63 \%$ in pedodontics, $4.81 \%$ in orthodontics, $4.15 \%$ in periodontology, $3.65 \%$ in restorative dentistry, and $3.15 \%$ in oral and maxillofacial radiology.

As presented in Tables 1 and 2, the most common reply provided to the question "Are zoonoses transmitted from animals to humans?" was "Rarely" (56.38\%), to the question "Can zoonoses be transmitted by a healthy animal?" was "Yes" (65.3\%), and to the question "Are zoonoses transmitted human-to-human?" was "Yes" (89.1\%). Similarly, the most common reply provided to the question "Are zoonoses life-threatening?" was "Yes" (97.35\%), to the question "Can zoonoses be eradicated?" was "Partially" (52.07\%), and to the question "What/who is the primary source of information you would apply to in a case of a health problem related to zoonoses?" was "Relevant specialists" (83.08\%).

Table 2 presents the participants' perceived level of knowledge regarding zoonoses. Of all participants, $62.35 \%$ believed that dental professionals have a role in the treatment of zoonoses and $96.35 \%$ stated no problems regarding zoonoses during their professional practice.

In the question "Which of the following well-known diseases are zoonoses (rabies, tuberculosis, bird flu, SARS, tularemia, yersinia, leishmaniasis, capillariasis, brucellosis, anthrax, malaria, CCHF, salmonella, and HIV)?," each correct reply was scored as 1 point, and thus the maximum score was determined as 14 , and the participants that had a score of 14 were considered as having a knowledge level of $100 \%$. Accordingly, the mean score of participants was 8.02, which corresponded to a knowledge level of $58.57 \%$. In the question "Which animals can zoonoses be transmitted by (poultry, birds, rodents, pets, bovines, sheepgoats, wild animals, and prey animals)?," the maximum score was determined as 8 , and the mean score of the participants was 7.47 , which corresponded to a knowledge level of $93.37 \%$. In the question "What are the transmission modes of zoonoses (animalhuman, animal-animal, human-human, and human-animal)?," the maximum score was determined as 4 , and the mean score was 2.58 , which corresponded to a knowledge level of $64.5 \%$.

Rabies, CCHF, anthrax, bird flu, and brucellosis were the most commonly selected zoonoses by the participants; however, $3.2 \%$ and $11.3 \%$ of participants misidentified hepatitis $\mathrm{B}$ virus (HBV) and tetanus as zoonoses, respectively. Moreover, $84.4 \%$ of participants responded to the question "Which animals can zoonoses be transmitted by?" as "All". Moreover, the question "What are the transmission modes of zoonoses?" was answered by $99.8 \%$ of participants as "animal-human," $69.3 \%$ as "animalanimal," 66\% as "human-human," and $23.5 \%$ as "humananimal".

The question "What agents can zoonoses be caused by (bacterial, viral, parasitic, fungal)?" was answered by $87.2 \%$ of the participants as "viral," $85.7 \%$ as "parasitic," $79.1 \%$ as "bacterial," and $44.6 \%$ as "fungal." Furthermore, $40.4 \%$ of the participants believed that all four agent types were responsible for zoonoses, $27.53 \%$ believed that three of them were responsible, $19.24 \%$ believed that two of them were responsible, and $12.44 \%$ believed that only one of them was responsible.

Participants who were specialized in pedodontics, oral and maxillofacial radiology, and restorative dentistry had a significantly higher level of knowledge about the types of zoonoses compared to non-specialized participants $(\mathrm{p}<0.05)$. Similarly, participants who were specialized in oral and maxillofacial radiology had a significantly higher level of knowledge about the types of zoonoses compared to participants who were specialized in oral and maxillofacial surgery, orthodontics, prosthetic dentistry, and endodontics $(\mathrm{p}<0.05)$. However, no significant difference was established among other fields of specialty about the knowledge level on the types of zoonoses $(p>0.05)$. The specialized participants provided a higher number of correct replies compared to the nonspecialized participants; however, no significant difference was found between the two groups in the level of knowledge about zoonoses, the animals that could transmit zoonoses, and the transmission modes of zoonoses ( $>0.05$ for all) (Table 3).

Participants who were working in a private clinic had a lower level of knowledge regarding zoonoses compared to participants who were enrolled in a specialty program or doctoral degree $(\mathrm{p}<0.05)$. However, no significant difference was found among the professional settings of participants in the level of knowledge about the animals that could transmit zoonoses and transmission modes of zoonoses ( $p>0.05$ for both) (Table 4). 
Contrarily, 96.19\% of the participants reported no knowledge about the "One Health" concept. Similarly, 99\% indicated that they had received no training on this concept. Additionally, no significant relationship was found between the knowledge level and the acquisition of the training on the "One Health" concept and the participants' year of graduation, professional setting, and field of specialty $(p>0.05)$. Similarly, no significant relationship was found between the participant's views on the role of dental professionals in the fight against zoonoses and their year of graduation, professional setting, and field of specialty $(\mathrm{p}>0.05)$.

\section{Discussion}

Zoonoses have become more prevalent within the last five decades due to the large-scale changes in ecological and anthropogenic factors, which equally increased the potential risk of zoonoses for public health (22-25). Additionally, almost $60 \%$ of all human pathogens are zoonotic and the number of novel pathogens continually increased, which indicates the seriousness of zoonoses and the socioeconomic losses caused by these diseases (26). Previous studies evaluated various serious zoonoses in Turkey, including toxoplasmosis, tuberculosis, anthrax, hydatid cyst, and rabies, and predominantly investigated their transmission modes, sources, and the number of infected individuals (2730). Kakkar et al. (30) examined the level of awareness among medical and veterinary students on zoonoses. Nevertheless, to our knowledge, no study had evaluated the knowledge level of dental professionals regarding zoonoses and their level of awareness on the "One Health" concept.

Zoonotic pathogens can be transmitted in either direction between humans and animals (31). Our study revealed that most of our participants $(99.8 \%)$ declared that zoonoses are transmitted from animals to humans and $89.05 \%$ considered that zoonoses are transmitted from humans to humans. Body fluids play an important role in the transmission of zoonoses from humans to humans. Droplets and aerosols are commonly known to be generated during most dental clinical procedures (32). Meaningfully, inhaling or direct contact with these particles leads to the human-to-human transmission of zoonoses (17). Therefore, dental professionals need to have high-level awareness of the transmission of zoonoses and take necessary precautions.

Our study revealed that $23.5 \%$ of the participants considered that zoonoses are transmitted from humans to animals. However, only several zoonoses, including Mycobacterium tuberculosis, Staphylococcus infections (predominantly methicillin-resistant Staphylococcus aureus), and Cryptosporidium parvum are known to be rarely transmitted from humans to animals (33). Contrarily, most participants $(56.38 \%)$ indicated that zoonoses are rarely transmitted from animals to humans, which indicates their low level of knowledge regarding this transmission mode. Meaningfully, this low level of knowledge could be attributed to the fact that the transmission of zoonoses to animals is a major field of interest among veterinarians.

Practitioners, physicians, nurses, health technicians, and other healthcare professionals need to undergo continuing vocational training (CVT) schemes that provide extensive information on access to information sources, dynamic zoonoses prevention, and public protection against zoonoses. Furthermore, studies that are conducted in Turkey and other countries showed that the administration of CVT schemes can prevent economic losses in healthcare services and reduce professional risks associated with zoonoses $(25,27)$.

Taştan et al. (27) evaluated the knowledge level of nurses regarding zoonoses and revealed that the most common reply provided to the question "What/who is the primary source of information you would apply to in a case of a health problem related to zoonoses?" was "Relevant specialists" (40.5\%), followed by "Internet" (27.9\%), and the least common reply was "Television" (0.4\%) (27). These findings were consistent with our findings since "Relevant specialists" (83.08\%) was also the most common reply provided by our participants, followed by "Internet" (28.05\%), "Colleagues" (28.5\%), and the least common reply was "Books" (8.3\%). Çilingiroğlu et al. (11) evaluated the knowledge, opinions, and behaviors of adults regarding CCHF and revealed that television (94\%) was the most common information source among the participants, followed by healthcare professionals (7.4\%), health centers $(6.4 \%)$, and internet (4\%). These findings were inconsistent with our findings, which could be attributed to the fact that our participants were dental professionals, and the participants in the study by Çilingiroğlu et al. (11) consisted of non-healthcare professionals who had a higher potential of television viewing.

Taştan et al. (27) revealed that 59\% of their nurse participants had insufficient knowledge about zoonoses. Similarly, 60.86\% of our participants revealed that they had insufficient knowledge about zoonoses. These low knowledge levels are highly important in protective health services, risk management in public health services, health economy, and efficiency. Therefore, both dental professionals and other healthcare professionals should undergo multidisciplinary training on zoonoses, as well as intensive training schemes that provide updates on emerging zoonoses.

Taylor et al. (34) conducted a systematic review and identified 1,415 species of infectious organisms that are known to be pathogenic to humans, including 538 bacteria and rickettsia, 353 parasites, 307 fungi, and 217 viruses and prions. However, the participants in our study identified viral pathogens $(87.2 \%)$ as the most common cause of zoonotic infections, followed by parasitic $(85.7 \%)$, bacterial $(79.1 \%)$, and fungal $(44.6 \%)$ pathogens. These differences could be attributed to the worldwide impact of the widespread coverage of Coronavirus disease-2019 (COVID-19) on mass media and social media on the decisions of participants.

Our study revealed a significantly lower knowledge level of participants working in private clinics about zoonoses than those enrolled in a specialty program or doctoral degree $(\mathrm{p}<0.05)$. Contrarily, the specialized participants provided a higher number of correct replies compared to nonspecialized participants; however, no significant difference was found between the two groups in the level of knowledge about zoonoses $(p<0.05)$. 
These findings were consistent with the findings of studies that compared the knowledge level of specialized and nonspecialized dental professionals about other issues (35-37).

Zoonoses, particularly rabies, tuberculosis, bird flu, brucellosis, SARS, leishmaniasis, capillariasis, anthrax, malaria, CCHF, and HIV, remain a serious public health problem both in Turkey and other countries $(7,12)$. Hundal et al. (38) evaluated the awareness, knowledge, and risks of zoonoses among livestock farmers and revealed that the most commonly identified zoonosis among the participants was bird flu (92.4\%), followed by rabies $(84.8 \%)$, brucellosis (46.0\%), tuberculosis (32.8\%), and anthrax (4.61\%). Molineri et al. (39) evaluated the awareness levels of freshmen entering the veterinary school about zoonoses and revealed that the most commonly identified zoonoses among the participants were rabies, tuberculosis, and leptospirosis. Our study revealed that the mean score of the participants for the question "Which of the following well-known diseases are zoonoses?" was 8.02, which corresponded to a knowledge level of $58.57 \%$. Additionally, rabies was found to be the most well-known zoonosis among our participants, followed by CCHF (87.6\%), bird flu (85.7\%), and anthrax (85.1\%). These findings were consistent with those reported in the literature. Contrarily, HIV, which has a crosscontamination potential due in dental clinics, was identified as a zoonosis by $14.1 \%$ of our participants. We believe that HIV

Table 1. Questions in the survey
Question 1: What is your gender?
Question 2: What year did you graduate?
Question 3: Where do you work?
Question 4: What is your area of expertise?
Question 5: $\quad$ Is disease transmitted from animals to humans?
Question 6: Does zoonotic diseases threaten life?
Question 7: $\quad$ Can zoonotic diseases be eliminated?
Question 8*: Which are the Zoonosis Diseases?
Question 9*: Are the zoonotic diseases transmitted from which
animals?
Question 10*: Can zoonotic diseases be transmitted with which
transitions?
Question 11: Can zoonotic diseases be transmitted from person
to person?
Question 12*: What do pathogens cause zoonotic diseases?
Question 13*: Which information source do you first apply to
when you have a health problem with zoonotic diseases?
Question 14: Have you ever had a problem with zoonotic diseases
during professional practices?
Question 15: Do you think you have sufficient knowledge about
zoonotic diseases?
Question 16: Do you know the one health concept?
Question 17: Have you received any education on the one health
concept?
Question 18: Do you think the dentist has a role in the treatment
of zoonotic diseases?
*In these questions, the participants were able to mark more than 1 option

should be better known than rabies by dental professionals. Additionally, HBV, which is a non-zoonotic disease and a critical entity in dental clinical practice, was identified as a zoonosis by $3.2 \%$ of the participants. These findings implicate the need for health professional education.

Zoonoses may be transmitted by contact with all contaminated animals, including poultry, birds, rodents, pets, cattle, bovines, sheep-goats, wild animals, and prey animals (5). Our study revealed that the mean score of participants for the question "Which animals can zoonoses be transmitted by" was 7.47 , which corresponded to a knowledge level of $93.37 \%$. This finding indicates that participants did not know all the types of zoonoses; however, they had sufficient knowledge on which animals had the potential to transmit these diseases.

Zoonoses are a leading cause of death from infectious diseases worldwide $(8,9)$. Among these, SARS and bird flu that emerged in the 2000s and the current COVID-19 pandemic that influences the entire world remain the most fatal zoonoses $(17,40,41)$. The present study revealed that $97.35 \%$ of participants identified zoonoses as life-threatening. Accordingly, raising the awareness of dental professionals, particularly, on the zoonoses that are transmitted via airborne droplets and particles, and supporting the measures to be taken against these diseases are of prime importance.

The "One Health" concept emerged as an internationally significant phenomenon that follow the outbreak of bird flu in the early twenty-first century (42). Zoonoses can emerge in any part of the world, thus worldwide measures need to be taken to keep track of, prevent, and cope with these diseases (43). A previous study by Wong and Kogan evaluated the views of second to fourth-year veterinary medicine students at the Colorado State University College of Veterinary Medicine and Biomedical Sciences on the needs and attitudes regarding the "One Health" concept. The students were involved in educational activities that included interdisciplinary interactions with health professionals and revealed that most of the students were highly interested in the activities and that this model was remarkably effective (44). Such activities are considered to become widespread both in Turkey and worldwide.

Our study revealed that $99 \%$ of participants received no training on the "One Health" concept and $96.19 \%$ had no prior knowledge about this concept. Additionally, 62.35\% considered that dental professionals had a role in the treatment of zoonoses. The lack of knowledge about the "One Health" concept among dental professionals, as well as other health professionals, results from their lack of training on these diseases. Accordingly, activities on zoonoses are considered to be promoted, and training schemes should be conducted to eliminate deficiencies in the systems to prevent these diseases. The present study aimed to elucidate zoonoses and the application of the "One Health" concept in dental practice, as well as raise awareness in clinical practice and contribute to the relevant literature. 
Table 2. The distribution of given answers

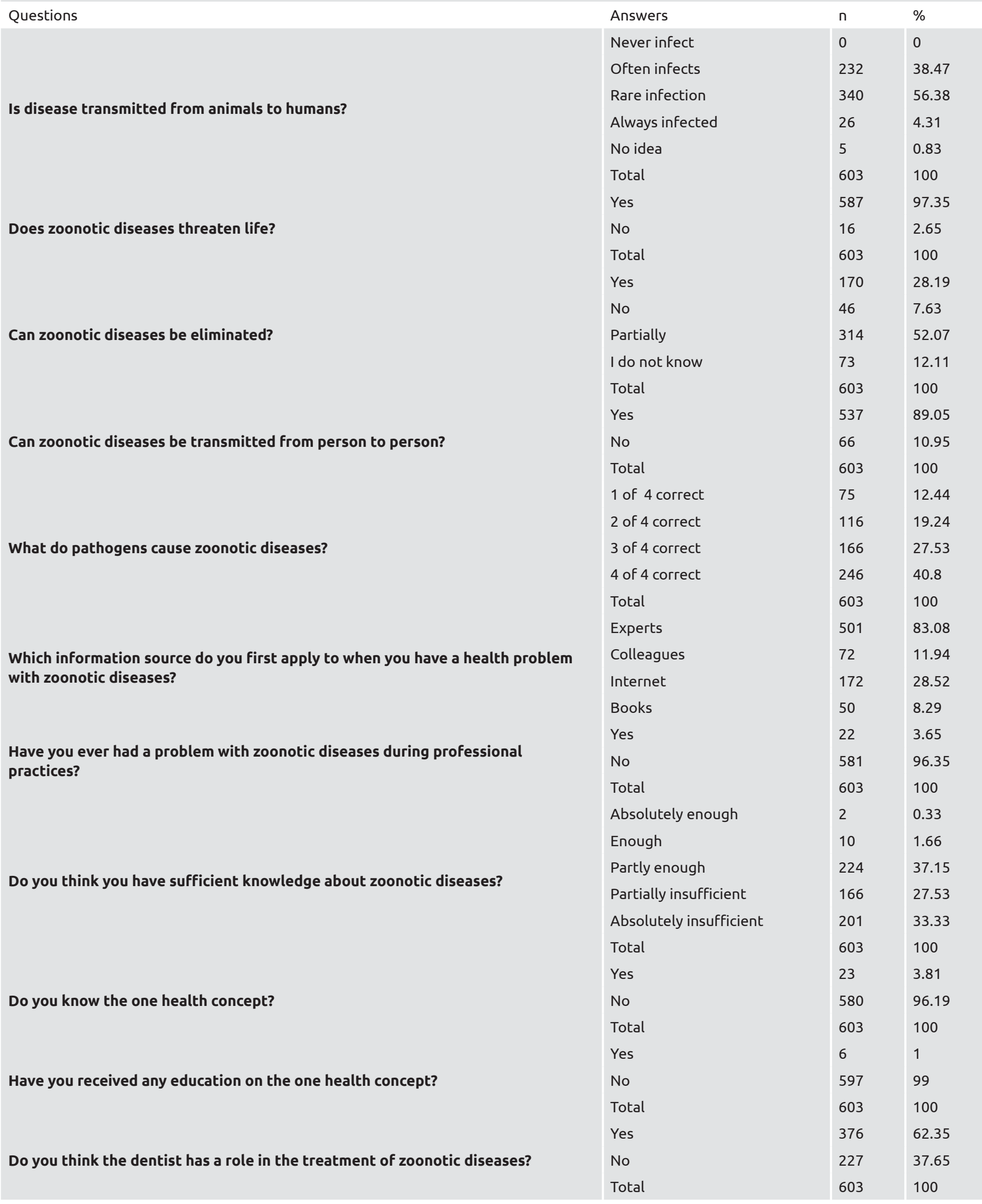


Table 3. The result of the analysis on the difference between the areas of expertise

\begin{tabular}{|c|c|c|c|c|c|c|c|c|c|c|}
\hline \multirow[b]{2}{*}{ Questions } & \multirow[b]{2}{*}{ The areas of expertise } & \multirow[b]{2}{*}{$\mathrm{n}$} & \multirow[b]{2}{*}{ Mean } & \multirow[b]{2}{*}{ Median } & \multirow[b]{2}{*}{ Min } & \multirow[b]{2}{*}{ Max } & \multirow[b]{2}{*}{ SD } & \multicolumn{3}{|c|}{ Kruskal-Wallis H testi } \\
\hline & & & & & & & & $\begin{array}{l}\text { Mean } \\
\text { Rank }\end{array}$ & $\mathrm{H}$ & $\mathrm{P}$ \\
\hline & Pediatric dentistry & 40 & 8.87 & 9 & 4 & 14 & 2.27 & 356.73 & & \\
\hline & Oral, dental and maxillofacial surgery & 72 & 8.24 & 8 & 3 & 13 & 2.25 & 316.15 & & \\
\hline & Orthodontics & 29 & 8 & 8 & 4 & 12 & 2.31 & 295.07 & & \\
\hline & Mouth. tooth and jaw radiology & 19 & 9.47 & 10 & 5 & 12 & 2.25 & 409.71 & 19654 & 0012 \\
\hline & Restorative dental treatment & 22 & 8.86 & 9 & 6 & 13 & 2.01 & 361 & & \\
\hline & Endodontics & 41 & 7.76 & 8 & 2 & 12 & 2.59 & 286.93 & & \\
\hline & None & 308 & 7.74 & 8 & 2 & 13 & 2.21 & 281.25 & & \\
\hline Are the & Orthodontics & 29 & 7.41 & 8 & 3 & 8 & 1.45 & 295.59 & & \\
\hline zoonotic & Prosthetic dental treatment & 47 & 7.23 & 8 & 2 & 8 & 1.59 & 272.79 & & \\
\hline dransmitted & Periodontology & 25 & 7.56 & 8 & 3 & 8 & 1.29 & 310.86 & & \\
\hline from which & Mouth, tooth and jaw radiology & 19 & 7.26 & 8 & 4 & 8 & 1.48 & 283.87 & 6.298 & 0.614 \\
\hline animals? & Restorative dental treatment & 22 & 7.77 & 8 & 3 & 8 & 1.07 & 332.5 & & \\
\hline & Endodontics & 41 & 7.32 & 8 & 2 & 8 & 1.72 & 300.45 & & \\
\hline & None & 308 & 7.49 & 8 & 1 & 8 & 1.4 & 303.51 & & \\
\hline & Total & 603 & 7.47 & 8 & 1 & 8 & 1.4 & & & \\
\hline & Pediatric dentistry & 40 & 2.75 & 3 & 1 & 4 & 1.08 & 331.58 & & \\
\hline & Endodontics & 41 & 2.71 & 3 & 1 & 4 & 0.98 & 324.96 & & \\
\hline & None & 308 & 2.59 & 3 & 1 & 4 & 0.97 & 302.69 & & \\
\hline & Total & 603 & 2.58 & 3 & 1 & 4 & 0.99 & & & \\
\hline
\end{tabular}

\section{Conclusion}

Zoonoses will exist as long as humans and animals persist. The emergence of novel diseases may not be preventable; however, humans can be protected by the prevention of the spread of zoonoses. Therefore, dental professionals and other health professionals need to learn about and adopt the "One Health" concept. Further larger-scale studies with larger numbers of participants are needed to substantiate our findings.
Raising the awareness of all dentists about diseases that can be transmitted by airborne particles and droplets, particularly about zoonoses, and supporting the measures to be taken against zoonoses in dental practices is of great importance.

In addition to the clinical medical courses that are delivered in dentistry education, a course, such as infectious diseases, can be added, or regular training seminars can be organized to increase awareness on the duties of dentists in zoonoses and their transmission paths, prevention methods, and treatment methods. 
Table 4. Analysis result regarding the difference between the places studied in terms of knowledge scores

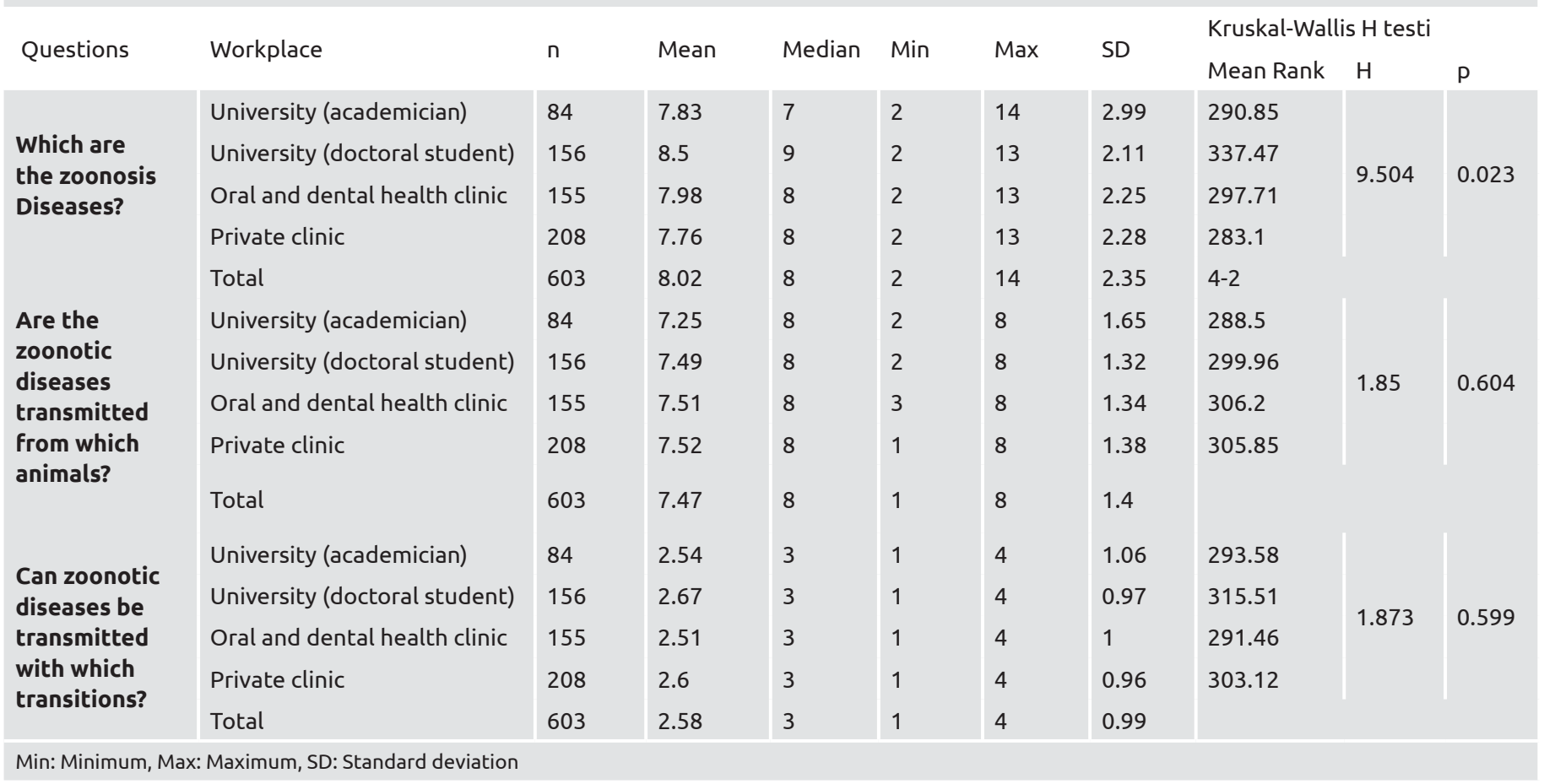

\section{Ethics}

Ethics Committee Approval: Before the study, approval was obtained from Firat University Non-interventional Clinical Research Ethics Committee (approval date: March 5, 2020; no: 2020/05-08).

Informed Consent: Each participant was informed about the goals and anticipated outcomes of the study.

Peer-review: Externally peer reviewed.

\section{Authorship Contributions}

Concept: E.E.Ç., A.Ç., Design: E.E.Ç., A.Ç., Data Collection or Processing: E.E.Ç., A.Ç., Analysis or Interpretation: E.E.Ç., A.Ç., Literature Search: E.E.Ç., A.Ç., Writing: E.E.Ç., A.Ç.

Conflict of Interest: No conflict of interest was declared by the authors.

Financial Disclosure: The authors declared that this study received no financial support.

\section{References}

1. Winer JN, Nakagawa K, Conrad PA, Brown L, Wilkes M. Evaluation of medical and veterinary students' attitudes toward a one health interprofessional curricular exercise. J Interprof Care 2015:29:49-54.

2. Dhama K, Tiwari R, Chakraborty S, Kumar A, Karikalan M, Singh $\mathrm{R}$, et al. Global warming and emerging infectious diseases of animals and humans: current scenario, challenges, solutions and future perspectives-a review. Int J Cur Res 2013;5:1942-58.

3. Salyer SJ, Silver R, Simone K, Behravesh CB. Prioritizing zoonoses for global health capacity building-themes from one health zoonotic disease workshops in 7 countries, 2014-2016. Emerg Infect Dis 2017;23:55-64.

4. Frentzel H, Menrath A, Tomuzia K, Braeunig J, Appel B. Decontamination of highrisk animal and zoonotic pathogens. Biosecurity and bioterrorism: biodefense strategy, practice, and science. Biosecur Bioterror 2013;11:102-14.

5. İnci A, Doganay $M$, Ozdarendeli A, Düzlü Ö, Yıldırım A. Overview of Zoonotic Diseases in Turkey: The One Health Concept and Future Threats. Turkiye Parazitol Derg 2018;42:39-80.

6. Authority EFS. The community summary report on trends and sources of zoonoses, zoonotic agents and antimicrobial resistance in the european union in 2004. EFSA J 2005;3:310ar.

7. Wang LF, Crameri G. Emerging zoonotic viral diseases. Rev Sci Tech 2014;33:569-81.

8. Calistri P, Iannetti S, Danzetta ML, Narcisi V, Cito F, Di Sabatino D, et al. The components of 'One World - One Health' approach. Transbound Emerg Dis 2013;60:4-13.

9. American Veterinary Medical Association (AVMA): One Health: A New Professional Imperative. One Health Initiative Task Force: Final Report, July 15, 2008. Available at: http:// www. worldrabiesday.org/assets/files/onehealth_final.pdf. Accessed: August 5, 2012.

10. Grace D, Gilbert J, Randolph T, Kang'ethe E. The multiple burdens of zoonotic disease and an Ecohealth approach to their assessment. Trop Anim Health Prod 2012;44:67-73.

11. Çilingiroğlu N, Temel F, Altıntaş H. Public's knowledge, opinions and behaviors about Crimean-Congo Hemorrhagic Fever: An example from Turkey. J Vet Fac Kafkas Unv 2010;16:17-22. 
12. Cascio A, Bosilkovski M, Rodriguez-Morales AJ, Pappas G. The socio-ecology of zoonotic infections. Clin Microbiol Infect 2011;17:336-42.

13. Williams CJ, Scheftel JM, Elchos BL, Hopkins SG, Levine JF. Compendium of veterinary standard precautions for zoonotic disease prevention in veterinary personnel: National Association of State Public Health Veterinarians: Veterinary Infection Control Committee 2015. J Am Vet Med Assoc 2015;247:1252-77.

14. Schwabe CW. Veterinary medicine and human health. 1964.

15. Zinsstag J, Schelling E, Waltner-Toews D, Tanner M. From "one medicine" to "one health" and systemic approaches to health and well-being. Prev Vet Med 2011;101:148-56.

16. Gibbs EPJ, Anderson TC. One World-One Health'and the global challenge of epidemic diseases of viral aetiology. Vet Ital 2009;4:35-44.

17. Samaranayake LP, Peiris M. Severe acute respiratory syndrome and dentistry: a retrospective view. J Am Dent Assoc 2004;135:1292-302.

18. Peng X, Xu X, Li Y, Cheng L, Zhou X, Ren B. Transmission routes of 2019-nCoV and controls in dental practice. Int J Oral Sci 2020;12:9-15.

19. Péron F, Rat-Fischer L, Lalot M, Nagle L, Bovet D.Cooperative problem solving in African grey parrots (Psittacus erithacus). Anim Cogn 2011;4:545-53.

20. Barrett MA, Bouley TA, Stoertz AH, Stoertz RW. Integrating a One Health approach in education to address global health and sustainability challenges. Front Ecol Environ 2011;9:329-45.

21. Hancer M. Translating questionnaires to other languages and different methods Balıkesir Üniversitesi Sosyal Bilimler Enstitüsü Dergisi 2003;6:47-59.

22. Snedeker K, Anderson M, Sargeant J, Weese J. A survey of Canadian public health personnel regarding knowledge, practice and education of zoonotic diseases. Zoonoses Public Health 2013;60:519-25.

23. WHO, UNICEF. Global report for research on infectious diseases of poverty 2012. Geneva: World Health Organization, 2012.

24. Durmaz R, Doganay M, Sahin M, Percin D, Karahocagil M, Kayabas U, et al. Molecular epidemiology of the Bacillus anthracis isolates collected throughout Turkey from 1983 to 2011. Eur J Clin Microbiol Infect Dis 2012;31:2783-90.

25. Aral GA, Elhan HA, Akarsu C. Retrospective evaluation of Toxoplasma gondii seropositivity in fertile and infertile women. Microbiyol Bul 2011;45:174-80.

26. Gönen I, Soysal A, Topuzoğlu A, Bakir M. Clinical knowledge and attitudes of Turkish physicians toward rabies caused by animal bites. Jpn J Infect Dis 2011;64:382-90.

27. Taştan R, Altıntaş L, Cevizci S. The determination of knowledge level of nurses working in the hospitals in the center of Kocaeli province about the zoonotic diseases. J Turkish Bulletin of Hygiene and Experimental Biology 2016;73:365-78.

28. World Health Organization. Report of the WHO/FAO/OIE joint consultation on emerging zoonotic diseases. World Health Organization: Geneva: World Health Organization, 2004.
29. Messenger AM, Barnes AN, Gray GC. Reverse zoonotic disease transmission (zooanthroponosis): a systematic review of seldomdocumented human biological threats to animals. PLoS One 2014;9:e89055.

30. Kakkar M, Ramani S, Menon G, Sankhe L, Gaidhane A, Krishnan. 'Zoonoses? Not sure what that is...'An assessment of knowledge of zoonoses among medical students in India. Trans R Soc Trop Med Hyg 2011;105:254-61.

31. Christou L. The global burden of bacterial and viral zoonotic infections. Clin Microbiol Infect 2011;17:326-30.

32. Sabino-Silva R, Jardim ACG, Siqueira WL. Coronavirus COVID-19 impacts to dentistry and potential salivary diagnosis. Clin Oral Investig 2020;24:1619-21.

33. Narrod C, Zinsstag J, Tiongco M. A one health framework for estimating the economic costs of zoonotic diseases on society. Ecohealth 2012;9:150-62.

34. Taylor LH, Latham SM, Woolhouse ME. Risk factors for human disease emergence. Philos Trans R Soc Lond B Biol Sci 2001;356:983-9.

35. Ciftci ME, Aktan AM, İsman O, Çiğdem A, Kundakoğlu Z. Level of knowledge of dentists in evaluation of anatomic landmarks on panoramic radiograp. J Atatürk Uni Fac Dent 2015;25:160-4.

36. Akbari N, Raeesi V, Khazaei T, Ramezanzadeh K, Ebrahimipour $S$. Evaluation of general dentists' and dental specialists' knowledge about oral cancer in South Khorasan-Iran 2014. Asian Pac J Cancer Prev 2015;16:6987-90.

37. Kapoor D, Bhatia S, Garg D. Assessment of the Attitude and Knowledge of the Principles and Practices of Orthodontic Treatment Among the Non-orthodontic Specialists and General Practitioner Dentists. JNMA J Nepal Med Assoc 2018;56:766-9.

38. Hundal JS, Sodhi SS, Gupta A, Singh J, Chahal US. Awareness, knowledge, and risks of zoonotic diseases among livestock farmers in Punjab. Vet World 2016;9:186-91.

39. Molineri AI, Signorini Porchietto ML, Ruiz ME, Ruiz ME, Marenghi MA, Tarabla HD. Awareness of zoonoses in freshmen entering the veterinary school. R Bras Ci Vet 2014;21:239-42.

40. Al-Hazmi A. Challenges presented by MERS corona virus, and SARS corona virus to global health. Saudi J Biol Sci 2016;23:507-11.

41. Zu ZY, Jiang MD, Xu PP, Chen W, Ni QQ, Lu GM, et al. Coronavirus disease 2019 (COVID-19): a perspective from China. Radiology. Accessed: Feb 21, 2020.

42. Artois M, Bicout D, Doctrinal D, Gavier-Widen D, Globig A, Hagemeijer W, et al. Outbreaks of highly pathogenic avian influenza in Europe: the risks associated with wild birds. Rev Sci Tech 2009;28:69-92.

43. Destoumieux-Garzón D, Mavingui P, Boëtsch G, Boissier J, Darriet F, Duboz P, et al. The one health concept: 10 years old and a long road ahead. Front Vet Sci 2018;5:14.

44. Wong D, Kogan LR. Veterinary students' attitudes on One Health: Implications for curriculum development at veterinary colleges. J Vet Med Educ 2013;40:58-62. 